\title{
THE PLACE OF ENGLISH IN RELATION TO OTHER LANGUAGES IN SOUTH AFRICA
}

Kathleen Heugh

English is undeniably important in tenns of fulfilling particular functions, but it does not, on its own, cater for the complex linguistic needs of a multilingual society. Experience elsewhere in Africa has shown that an assimilationist and/or interactional perspective is a dangerous position to adopt. It is unlikely to serve best the interests of the majority of South Africans. Two case studies (Zimbabwe and Nigeria) are used to argue this position. In South Africa the multilingual policy that is likely to be adopted may result in a continued hegemony of English. A proactive policy of establishing multilinguasm as resource is advocated instead in the interests of future democracy.

Engels is ongetwyfeld belangrik in tenne van die verskeidenheid funksies wat dit vervul, maar dit kan nie op sigseif voorsiening maak vir die komplekse behoeftes van 'n multi-linguistiese gemeenskap nie. Ondervinding elders in Afrika het getoon dat 'n uitgangspunt wat of op assimilasie $6 f$ op interaksie gebaseer is, nie die gewenste uitwerking mag he nie. Dit is onwaarskynllk dat dit die belange van die meerderheid Suid-Afrikaners optimaal sal dien. Twee gevallestudies (Zimbabwe en Nigerie) word gebmik om hierdie standpunt te ondersk:ryf. In

Suid-Afrika mag die multi-linguistiese beleid wat waarskynlikaanvaar sal word, lei tot die hegemonie van Engels. In die belang van 'n toekomstige demokrasie word 'n pro-aktiewe beleid, wat multi-linguisme as redmiddel vestig, eerder voorgestaan.

There is a very real dichotomy between what is a likely scenario for English in South Africa and what many interest groups are claiming as a primary goal for a free South Africa. namely the equalising of opportunities. And many argue that this process can be advanced through appropriate language policy and planning.

There is little doubt that English will occupy some form of primacy in South Africa particularly in government, the economy and in educational provision. Yet there is a tension between the expediency of choosing a policy heavily dependent upon English anc the very real limitations this approach will have for the majority of South Africans.

The primacy of English is promoted by important stakeholders in the country. These include the business community; the progressive political blocs through their choice oJ English in which to conduct political discourse; and other interest groups such as the English Academy. An attitudinal survey conducted by Kotze and Southey in 198S concludes that urban black people want English in education from the onset of primal) education.

The favoured position of English within the liberation movements can be traced back tc 1912 with the leader of the African People's Organisation (APO), Abdurahman, advocatine English as the only viable national language for the country (Alexander, 1989:29-30). Apartheid and the rise of Afrikaner nationalism with the concomitant rise in status oJ Afrikaans disguised in South Africa the dangers of the hegemony of English. It is no1 surprising then that whereas in many other parts of Africa there is a growing concern aboul the way English has been used as an effective barrier to democratic practice, the recognition of this aspect of English is fairly underdeveloped here. 
rollefson (1991) ar es that a number of western market driven economies have a direct interest in advancing the hegemonic position of English, particularly in developing countries. He attributes this, in part, to the fact that language is used: as a mechanism for controlling access to power; and as an excuse for paying lower wages to speakers of other languages. Recent analyses of aid packages to the developing world suggest that major lonors seldom favour the promotion of access to power via indigenous languages. So it is tlso not surprising that the South African economic sector should vigorously support the continued privileged status of English. This coupled with a successful language policy lesigned to devalue African languages has led to a lack of confidence in the power of African languages.

The ANC document on language policy, Language Policy Considerations (1992), whilst acitly acknowledging English as the purveyor of elitism, indicates an acceptance of the primacy of English in education. This ambivalence is typical of policy statements in other nultilingual countries in Africa.

This document affirms reference to language endorsed in the Freedom Charter (1955) that 'All people shall have equal rights to use their own languages and develop their own folk culture md customs". It further asserts: "the ANC supports the deliberate fostering of multilingualism $n$ schools, adult education programmes, in the workplace and in all sectors of public life..."

However, under a section on language in education, the document notes that:

Though language experts argue that initial education is best conducted through the 'mother tongue' ...., large sections of black urban communities have already pressurised primary schools into beginning with English as the medium of instruction from day one.... Any language policy must reflect the voice of the people and this voice is more important than any model which emerges.

y implication then, there is a strong suggestion from the ANC that should it be the will of he people, English shall occupy the position of primary linguistic importance in education

$>$ Ver all other languages. Further the implication is that most of 'the people' are pushing or English because they acknowledge the instrumental value of English in the status quo md imagine that this would be the case for the future as well.

At the same time the ANC document shows a concern for the development of African languages. At this point, though, the ANC has clearly not developed a strategy to reconcile wo opposing forces. This problem is reflected via the media. City Press ran an article entitled, English likely to get ANC's vote (Sello, 1992), in which it was argued that although the ANC accorded all eleven South African languages equal status, the reality would be that English would be the official language.

Nevertheless, the ANC Education Desk has recently commissioned the Centre for Education Policy Development (CEPD) to arrive at a model for lai1!JI!:.age in education which will be based upon principles of access, equity and empowerment (Constable and Musker, .993). There are strong indications that this group will propose a far more coherent Position on language and one accompanied by an effective strategy for the implementation of policy.

The work of the CEPD group is very similar to proposals for language policy in education which have been put forward by the National Language Project (NLP). Since 1986 the NLP has taken a position that the validation of our multilingual society is an integral component if democracy. The NLP suggests that English should occupy the position of lingua franca until such time as another language emerges to fulfil this function. However, that in andem with English, other South African languages should be recognized as official regional languages, thereby altering and rehabilitating the status of these languages significantly. 
Set against all the arguments and pressures toward the primacy of English where English is adopted from an assimilationist and/or internationalist perspective is an overwhelming set of experiences from other parts of the developing world, and in particular from anglophobe Africa, which suggest that this is a dangerous position to adopt. It is one, in fact, which is unlikely to serve best the interests of the majority of South Africans.

\section{TWO CASE STUDIES: ZAMBIA AND NIGERIA}

A brief glimpse of language policy and its implementation in two other African countries, each of which has adopted somewhat differing approaches after independence, may provide us with useful pointers to the complexity of the debate. Hopefully, it will also give us sets of criteria which might inform any future decisions in South Africa.

\section{ZAMBIA}

At the NLP Conference on Democratic Approaches to Language Planning and Standardisation in 1991, Kathleen Siachitema, from the University of Zambia, analysed the failure of Zambia's language policy during the post-independence period. Zambia went for an English-only policy after independence. English was chosen in the interests of building a politically integrated nation and indigenous languages were seen as posing a threat to this process.

Access to English in Zambia is primarily throuh formal education, a costly and lengthy process in Siachitema's view. Zambia's finanCial resources have not been sufficient to ensure that the majority of citizens have access to formal education for a sufficient period to ensure linguistic competence. And given that initial mother tongue instruction was disre arded in favour of English from day one, the majority of Zambians are not even functwnally literate in their own first language. Consequently, those who have had access to English have become a small educated elite.

Secondly, since access to English is the criterion for any individual to participate in the national political and economic system, the majority have no way of participating in the system. Apart from the high drop-out rate in urban schools, the rural masses have been educationally and politically marginalised.

Thirdly, The prominence that has been given to the English language in the national system has rendered the local languages instrumentally valueless..(Siachitema, 1992:19).

Fourthly, since access to the economy is through an English dominated educational system, the majority of people feel barred from this domain as well.

Fifthly, an attitudinal study conducted by Siachitema reveals that the educated elite and the uneducated masses are divided in their attitude to language and to English, in particular.

Siachitema concludes that since not much political integration could have taken place in Zambia because the masses are not involved in the national system... there is no feeling of attachment and integration...(19).

As far as the usage of English is concerned, Tripathi (University of Addis Ababa, Ethiopia) in a recent publication has explored the nature of this language in Zambia. He found that there is a growing use of an informal variety of English, amongst the English-speaking minority, which differs phonologically, semantically and syntactically from standard British English. He suggests that it will be impossible, even with comprehensive educational intervention, for a standard British English to become the norm of spoken usage in Zambia. He questions, therefore, the cu"ent importance and popularity of English as 'the truly international' language... and further he argues that a much smaller proportion of the 
:ambian elite now speak and write like educated Englishmen, although or even because the ) $p$ of the English-speaking pyramid has become more accommodating than before. With the ?read of English and the inevitable dilution of norms, the gap between the best and the worst :nglish usage in Zambia would only become narrower and the gap between these and the 'ritish Standard wider (1990:37).

le refers here to English as it is used across the country, by what is still a minority. He rgues that spoken English is in the process of becoming p1dginized by its users and will !ways only be used for a limited number of special purposes. Referring to the majority 'ho do not have any access to any variety of English he comments: This would of course ave the majority out in the cold, on the fringe of the privileged, political nation (38).

le further casts doubt on whether a pidginized Zambian English would ever become tidespread because he notes that Zambians are not a trading nation, and most of them know vo or more of the major local languages and can communicate across linguistic divisions... In ze long run a mixed language with an indigenous base may emerge as the lingua franca of the ?untry and even replace English in official use(38).

\section{NIGERIA}

Hyi Akinnaso has recently written a seminal paper on Nigerian language policy, Toward the > evelopment of a Multilingual Language Policy in Nigeria, in which an approach different rom that adopted by Zambia is analysed. Essentially, he argues that two factors have 1fluenced Nigerian language planning:

uch factors have either (1) a nationalist orientation, such as adoption of indigenous 'national' mguages as a means of achieving national integration, or (2) an international focus, such as continental pressures, especially from the organization of African Unity, for the rejection of European or colonial languages and (b) global pressures to implement the famous UNESCO eclaration on mother tongue education (1991:29).

Despite these considerations, English has been chosen as the official language to function $\mathrm{s}$ the language of the government, the bureaucracy, education, 'higher' commerce, mass communication, international trade and politics, science and technology (Akinnaso, 991:35). Akinnaso notes that while English also functions as a lingua franca amongst the educated elite, it is pidgin English which occupies this domain in larger mformal contexts in various heterogeneous pockets throughout the country. Pidgin English is also extensively used in the media and informally in educational institutions although it holds a stigmatised status and no provision for it is made in any language policy documents.

11ree constitutions between 1960 and the present have retained English as the official mguage of the country. Major shifts have taken place, however, in terms of the status and orpus planning of indigenous Nigerian languages. Essentially three major Nigerian mguages have had the status of national language conferred upon them, viz Hausa, lgbo, nd Yoruba.

'he idea is that national unity might be promoted through indigenous national languages .

Jdnnaso argues that in Nigeria, political interests are sometimes in conflict with educational interests. Up until 1977 the question of medium of instruction was dealt with in way which is familiar to us in South Africa. The principle of initial mother tongue 15truction with a switch to English later was applied more or less consistently.

'he National Policy on Education of 1977, revised in 1981, states that in the interests of ational unity ... each child should be encouraged to learn one of the three major languages ther than his own mother-tongue (in Akinnaso:39). 
In essence, Nigerian educational language policy is multilingual. Initial mother tongu instruction is adhered to with a later switch to English as a medium. In addition, a thir language of national language identi1y is included at junior secondary level.

Akinnaso summarises Nigerian language policy objectives in the constitution and i education as:

1 the desire to achieve 'national unity' through the use of 'national' languages;

2 preservation of people's culture through preservation of their languages;

3 development and promotion of Nigerian languages; and

4 enrichment of the citizen's ability to communicate effectively in a multilingual socie( (41).

A central philosophy is the notion of equal opportuni1y.

Yet these objectives reflect tensions.

... the affinnation of cultural pluralism necessarily contrasts with the call for integration into 1 unified national culture, just as the continued use of English as the official language a government and much oj education clearly undennines the development of local language (41).

These tensions are not unique to Nigeria. Akinnaso suggests that there are four typica ideologies which underpin language policy in developing nations, viz linguistic pluralism linguistic assimilation, vemacularisation and internationalisation. The tension exists, $h$ argues, between the motivation for multilingualism vs monolingualism and indigenous $\mathrm{v}$ exogenous languages.

Where policy promotes multilingualism the ideology of linguistic pluralism is at wod However, while multilingualism is often overtly stated, linguistic assimilation is ofte implied. For example in Nigeria where there is an educational requirement for learning major national language, linguistic minorities often feel that they are being required t1 become assimilated into a dominant group. Further, where mother tongue is replaced b an international language, speakers of vernaculars see little value being accorded thei languages.

In terms of the instrumental value of languages in Nigeria, English is seen as the key t1 government, jobs etc. However, integration into local communities sociologicall) economically and politically, is "best facilitated by knowledge of the appropriate loca languages" (44).

At present, the language policies of Nigeria are not being implemented fully. In particula1 the policy regardinthe ac9.uisition of national languages. There are very clear instrumenta reasons for acquinng Enghsh in that English has the main gate-keeping function to ke areas of power and the international community. However, it is less clear why the nationa languages are instrumentally important.

Akinnaso suggests that more incentives need to be created around the learning of th national languages. And these need to be instrumentally bound. For example, he suggest that deadlines should be set; job opportunities, job advancement and access to tertiar institutions need to be tied to these languages (55). 
be key to finding a solution to the tensions amon st the approaches lies within the attempt J reconcile the notion of unity with diversity, 1.e. what Fishman calls nationism and ationalism. And Akinnaso predicts that for the foreseeable future developing nations will ontinue to advocate both linguistic unification (usually at the federal level) and linguistic luralism (usually at the regional/state level) while at the same time, retaining the appropriate ?lonial or world language for such specific purposes as education, administration, mass ?mmunication, international politics, or world trade (57).

\section{WHO MAKES POLICY DECISIONS?}

1. further key to the problem is something that both Akinnaso and Bamgbose (1989) kntify as the top-down approach to language policy and planning. They argue that it is ery difficult to implement a policy which is dictated by government ideology which does ot match the facts on the ground. So where policy is placed before fact-finding and valuation there will be difficulty in the implementation of policy.

lamgbose (1987) has proposed that language planning needs to reflect a flexible approach $\mathrm{J}$ the various components of language planning and policy formulation and this is omething for us to consider in South Africa. Alexander (1992:146), like Bamgbose and :humbow (1987), argues that language policy and planning left under the central control of he state is more likely to serve the interests of the ruling class and the economic :lfrastructure than the interests of the ordinary people.

:rawhall has further contributed to this line of argument. He notes that the tensions lescribed here in relation to language policy reflect a deeper tension within the postolonial African systems. Numerous other scholars, including Issa Shivji and Claude Ake, 1ave documented the unrelenting conflict of interests experienced by national elites in Gdependent African states.

nis conflict is between implementing policies which reinforce the colonial nature of the conomy, from which the elites benefit directly, and the other path of national and regional 'evelopment which will enhance democracy but potentially unseat the ruling class ( Crawhall, 1ersonal communication 1992).

\section{IMPLICATIONS FOR SOUTH AFRICA}

\{oung (1991) argues that very few empirical studies have been undertaken on language lttitudes in South Africa in recent years. He suggests that while there is an abundance of hetoric around language policy formulation in South Africa there is little empirical :vidence to support much of the discourse. In essence, he confirms the arguments of amgbose and Akinnaso that the implementation of any policy is dependent upon the 1rocess of fact-finding, policy-formulatiOn, policy-making and evaluation.

:be work done by Kotze and Southey in 1989 has indicated a preference for English from he word go. However, the 1992 Department of Education and Training's invitation for larents to choose the medium of instruction for their children revealed that two-thirds of hose parents who made a choice favoured initial instruction in the first language prior to a ;radual transfer to English. This may indicate a tentative shift in thinking away from the :arlier preoccupation with English reflected in the 1989 survey or that the earlier survey did tot delve deep enough into the realm of attitude.

)iachitema's work in Zambia indicated that amongst uneducated and marginalised groups here was a belief that proficiency in English was the only access point to power. And she :oncluded that this was because these people had been led to beheve through the practice >f Zambia's language policy that local languages had absolutely no instrumental value vhatsoever. Crawhall points out that similar studies in Zimbabwe showed that on the 
surface speakers of Shona believed that English was a more important language than Shona in terms of providing access to rewards. However, when researchers scratched the surface, people displayed a much stronger preference for usage of Shona. This would suggest then that we need a body of empincal research that scratches more than just surface attitude toward language, the relationship between power and language, and preferred language use in this country.

The long years of colonial and apartheid language policy in South Africa have effectively devalued our indigenous languages to the point where many speakers of these languages see little instrumental value in retaining them. This, as we have seen, is a common feature in Africa. Speakers of English and Afrikaans, here, have likewise come to believe this to be the case. However, if we are looking at a democratic future in which opportunities are equalised then we need to look again at whether this can be effected through English.

Bernd Heine at the Sociolinguistics in Africa conference at Wits in 1990, noted that in those countries which have chosen the ex-colonial language as the official language after independence, there are serious problems of linguistic communication. Conservatively, he estimates that less than $20 \%$ of African people are able to use their official language, with the exception of Nigeria where more than one fifth in fact do speak English. Phillipson (1988:350) asserts that English second language programmes have never had any success in the Third World, and Tollefson (1991) takes this further by arguing, that English language programmes have never proven to be successful in empowering marginalised communities anywhere.

The case of Zambia, where everythinhung upon the process of integration through the assimilation of diversity via the Enghsh-only policy, has deeply resonant bells for us in South Africa. Not only have national integration and the equalising of opportunities failed because of the emphasis on the English-only policy, but the use of English in Zambia has altered to the point that a shrinking elite use standard British English and a pidginised variety of English is developing which will in no way facilitate access to power, education or the international community.

The two major negotiating blocs, the present National Party government and the ANC, have the retention of the official status of Afrikaans and the equal status of all South African languages as their respective bottom lines on language policy. This means that there is unlikely to be a simple English only language policy for the country. It is much more likely given the discourse in r.rogressive interest groups that we will move in the direction of a multilingual policy sirrular, in many ways, to the Nigerian case.

What needs to be taken seriously is the mechanism for the implementation of policy. Statements of policy on their own are seldom efficiently implemented without a comprehensive strategy designed for such purpose. The conflicting tensions at work in the Nigerian case show qme clearly that an implementation strategy which is compatible with a language policy is an absolute necessity in order to achieve optimal success. At present, neither the present government nor the ANC have strategies $\mathrm{m}$ place to accompany their policies on language. This means that, through a process of default, the hegemony of English could continue, especially given the pressure from the interests of western economy. This, in turn, means that there will be very little progress made toward building democracy here.

If we were to operate primarily from the departure point of language as a resource, or more precisely, our multilingualism as a resource, and if we were to establish an effective mechanism for implementing a language policy informed by interest groups which include voices from below, we might be in a better position to advance democracy via a proactive language policy. 
In order to equalise opportunities in the country it would be necessary, among other obvious consideration, to look at what our langua es can functionally offer. Obviously English can offer rewards in terms of higher educational opportunities, power and money. But a proactive policy toward affording our major languages a gate-keepin\& role in regional levels of government, the economy, health care services etc would provide instrumental reasons for the development and acquisition of these languages. It has been an NLP recommendation for some time that access to tertiary institutions and jobs should be dependent upon a competency in at least one indigenous regional language.

Experience elsewhere in Mrica shows us that while English is undeniably important in terms of fulfilling particular functions it does not, on its own, cater for the complex linguistic needs of a multilingual society. 


\section{REFERENCS}

African National Congress, Department of Arts and Culture. 1992. ANC language policy considerations. Johannesburg: ANC.

Akinnaso, FN. 1991. Toward the development of a multilingual language policy in Nigeria. In Applied Linguistics, 12(1): 29-61.

Alexander, NE. 1989. Language policy and national unity in South Afn'cajAzania. Cape Town: Buchu Books.

Alexander, NE. 1992. Language planning from below. In Herbert, R K (ed), Language and society in South Afn'ca. Johannesburg: Witwatersrand University Press.

Bamgbose, A. 1987. When is planning not planning? Journal of West Afn'can Languages, 18:6-14.

Chumbow, B. 1987. Towards a language planning model for Africa. Journal of West Afn'can Languages, 18: 15-22.

Constable, P and Musker, P. 1993. Language in education-policy considerations. Paper presented at the READ conference in May.

Crawhall, N. 1992. Private communication.

Heine, B. 1990. Language policies in Africa. Paperfresented at the Sociolinguistics in Africa Conference at the University o the Witwatersrand, 30 January - 2 February.

Phillipson, R. 1988. Linguicism: Structures and ideologies in linguistic imperialism. In Skutnabb-Kangas, T and Cummins, J (eds), Minon'ty education: From shame to struggle. Clevedon: Multilingual Matters Ltd.

Sello, S. 1992. English likely to get ANC's vote. In City Press, 16 February.

Siachitema, AK. 1992. When nationalism conflicts with nationalist goals: Zambia. In Crawhall, NT (ed) Democratically speaking. Cape Town: National Language Project.

Tollefson, JW. 1991. Planning language, planning inequality. London: Longman.

Tripathi, PD. 1990. English in Zambia: the nature and prospects of one of Africa's 'new Englishes'. In English Today, 6(3): 34-38.

Young, D 1991. English in education in a post-apartheid South Africa. In: Webb, V N (ed) Language in South Afn'ca: an input to language planning for a postapartheid South Afn'ca. The (Provisional) LiCCA (SA) Research Report. 